\title{
The Third Sector in France and the Labour Market Policy 1
}

\author{
Edith Archambault
}

\section{Introduction}

In France, like in other Western European countries, the third sector has been on a steady increase during the last decades. Similar to the situation in Germany, the French third sector is predominately financed by public money that is concentrated on those subsections which form the core of the welfare state: education, health and social services. However, public funding is currently being reduced and against this background, government and nonprofit organisations are looking for new ways of co-operation. In other words, in France the partnership of the third sector with government is changing as well as its position and role in the French welfare mix.

In the following, the results of the Johns Hopkins Nonprofit Sector Comparative Project for France will be presented, thus outlining:

- the overall size of the third sector in France in 1995 ,

- its composition,

- its revenue sources, and

- its recent evolution.

Thereafter, In France, like in other Western European countries, the third sector has been on a steady increase during the last decades In France, many new jobs, new markets and new skills have initially been explored by volunteer work. Combined with a trend towards professionalisation, this knowledge served as a blueprint for paid labour. Moreover, the changing role of

1 An earlier version of this article has been published in Vol. One, No 2 of the Internet Journal German Policy Studies (HTTP://SPAEF:COM/GGPs_PUB/). 
the nonprofit organisations as partners in a new welfare mix will be analysed. The Centenary of 1901 Act gathered on July 1st many nonprofit leaders, many government representatives and fourteen ministers including the Prime Minister to sign a Charter of reciprocal commitments between the government and the nonprofit sector. It was also a kind of celebration of the government/nonprofit sector partnership. But beyond this temporary event, this relationship is not so clearly defined and in some subfields it includes a newcomer: the business sector.

\section{Dimension of the French nonprofit sector}

As stated elsewhere (Archambault 1997a, 1997b), the French nonprofit sector developed only quite recently; associations - the generic form for most nonprofit organisations - being illegal during the whole $19^{\text {th }}$ century until a centenarian act legalised them. During the 1960s and the 1970s the French Nonprofit Sector slowly grew in a context of state-provided welfare. More recently, the decentralisation of 1982 broke with a millenary Jacobean tradition which was a major incentive for the third sector to contract with local authorities. Graph 1 shows this recent growth: today between 60,000 and 70,000 new associations are created every year, more than three times the average of the $1960 \mathrm{~s}$.

Graph 1: Annual creations of associations, 1960/2001 


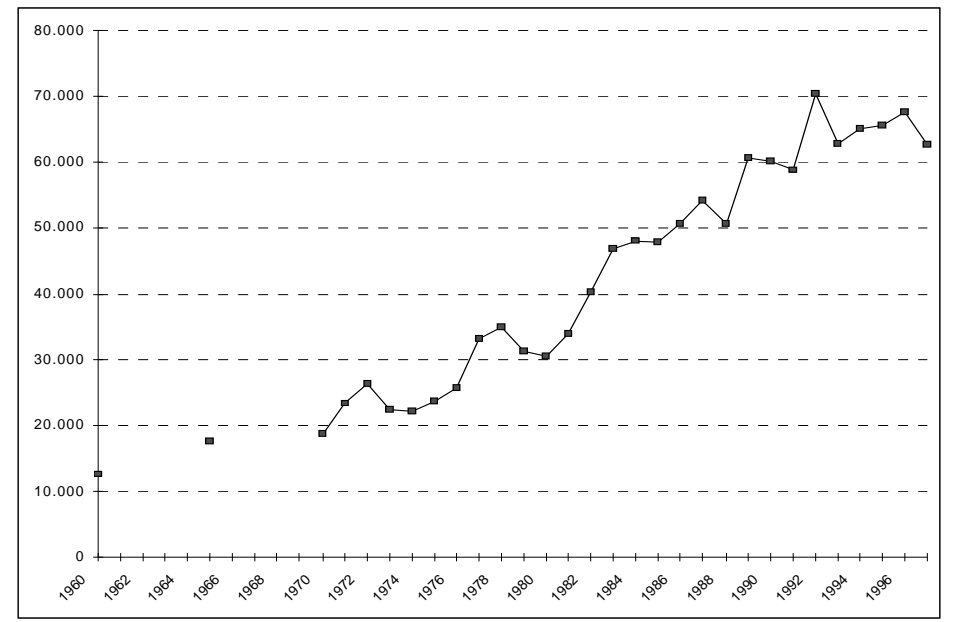

Source: Archambault, 2001

\subsection{Overall size of the French third sector}

In 1995 full-time-equivalent employment was 975,000 including religion and 960,000 excluding religion - that is 5 per cent of total employment, or the employment of all consumption-goods-manufacturing industries in 1995. In addition to this paid employment, 11 million of volunteers are working in the third sector. One French individual out of four declare to be a volunteer.

Graph 2: Nonprofit share of total employment by country, 1995 


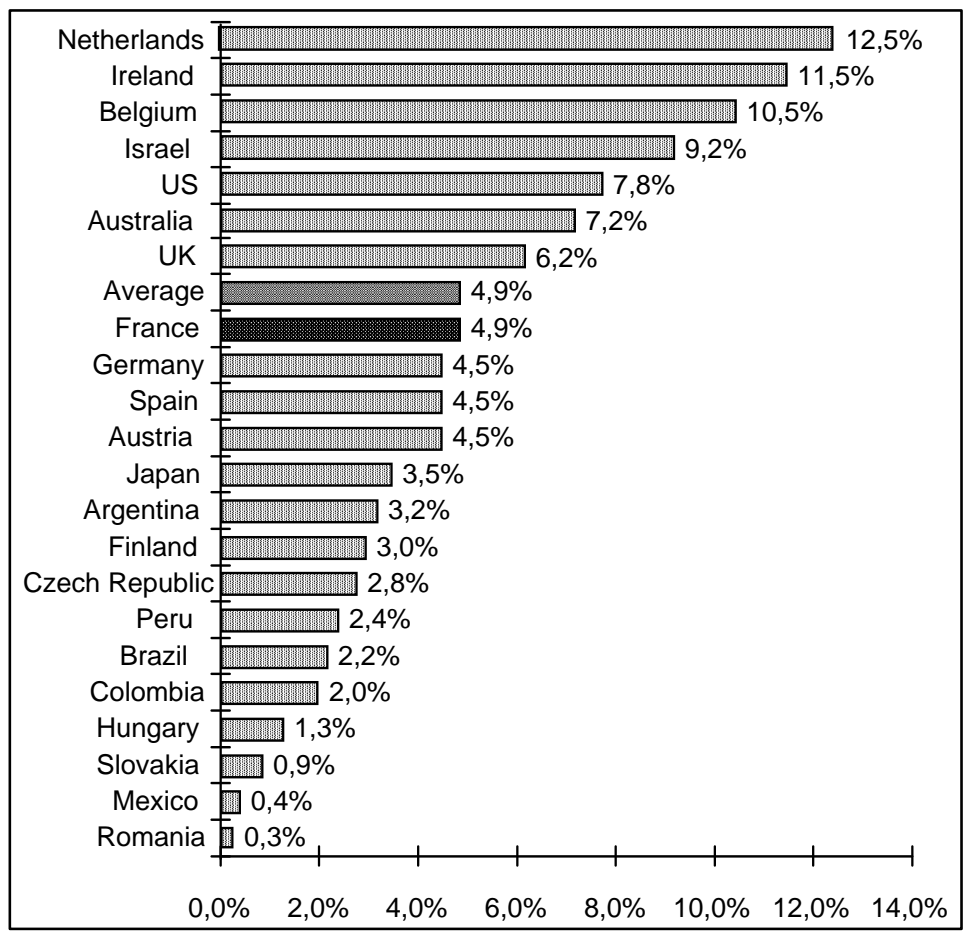

Source: Salamon et al. (1998).

The total operating expenditures of the third sector in 1995 was FF 290 billion ( 44.2 billion Euro), which is the equivalent of the turnover of the public utilities industry or the mechanical engineering industry. These figures do not include the estimated monetary value of volunteering which would raise the sum by some 70 per cent. Therefore, the economic activity of the French third sector - which is frequently a by-product of its social role is significant and sizeable. In a comparative perspective France is a "middle weight". Graph 2 shows the nonprofit share of total employment by country. The French third sector ranks exactly at the average level among the 22 countries included in the statistical part of the project. Germany is in a similar position.

However, in comparison to other Western European countries, the French and German third sectors are developed below the average - due to the fact that education as a significant area of nonprofit activity is primarily provided by public entities in both countries. 


\subsection{Composition of the French third sector}

The structure of the French nonprofit sector in 1995 can be seen in table 1 . The first column lists the organisations, or, more precisely, the percentage of establishments included in the SIRENE file, i.e. organisations which employ at least one salaried or which pay taxes. Out of a total number of nonprofit organisations, which is unknown (maybe 800,000 ), about 250,000 organisations are included in SIRENE file. The other columns show the percentage of the total operating expenditures, full-time equivalent employment (FTE), and volunteering (see above).

There are five significant features of the French nonprofit sector:

- From an economic point of view, the sector is concentrated on the core welfare activities - culture and recreation, education and research, health and social services - which represent 88 per cent of the total operating expenditures and the employment of the third sector, 80 per cent of the organisations recorded in SIRENE file, and 75 per cent of volunteer work.

- Just as the German Third Sector, the French sector is dominated by social services, and this dominance has recently even been increased with the deepening of the economic depression in 1993. Nonprofit organisations run 55 per cent of the overall number of residential care facilities, with a quasi-monopolistic position in the field of residential facilities for disabled persons.

- France has a higher percentage of third sector involvement in education than Germany has: about one fourth of the total resources of the nonprofit sector reside in the field of education. Catholic primary and secondary schools are over-represented in the western part of France, where the Belgian, or Dutch pattern prevails. All over the rest of France, private schools frequently represent a second chance for children rejected by public schools. Culture, sports and recreation is also more developed in France. This sub-sector has been growing rapidly ever since the government started its policy of decentralisation. Many small organisations - run mainly by volunteers - are mushrooming everywhere. Due to the fact that hospitals have been secularised, especially during the French Revolution, the percentage of third sector organisations active in the field of health is much lower in France than it is in Germany.

- There is a contrast between those sub-sectors which are highly professionnal like education, health and social services - where volunteer work still exists but at the margin, and where the division of labour is the rule - and those sub-sectors where volunteer work is the main resource, like culture, sports and recreation (which total nearly half of volunteering), or environment, international activities and professional associations.

- Philanthropic intermediaries and, more generally, all kinds of foundations - grantmaking, corporate or operating - are less numerous in France than in other industrial countries because they have been repressed for centuries. Before 1987, there was no law truly governing foundations and today there exist less than 500 independent foundations in France. 
Table 1: Structure of the French nonprofit sector, 1995

\begin{tabular}{|c|c|c|c|c|}
\hline Group & $\begin{array}{l}\text { Number of } \\
\text { organisations } \\
\text { (SIRENE file) } \\
\% \text { of total }\end{array}$ & $\begin{array}{l}\text { Operating } \\
\text { Expendi- } \\
\text { tures } \\
\% \text { of total }\end{array}$ & $\begin{array}{l}\text { FTE } \\
\text { employment } \\
\% \text { of total }\end{array}$ & $\begin{array}{l}\text { Volunteering } \\
\% \text { of total }\end{array}$ \\
\hline Culture and recreation & $41.6 \%$ & $15.5 \%$ & $12.1 \%$ & $46.7 \%$ \\
\hline Education and research & $15.7 \%$ & $24.8 \%$ & $20.7 \%$ & $8.9 \%$ \\
\hline Health & $2.4 \%$ & $14.5 \%$ & $15.5 \%$ & $3.4 \%$ \\
\hline Social services & $20.7 \%$ & $32.8 \%$ & $39.7 \%$ & $15.7 \%$ \\
\hline $\begin{array}{l}\text { Total } \\
\text { (the first } 4 \text { groups) }\end{array}$ & $80.4 \%$ & $87.6 \%$ & $88.0 \%$ & $74.7 \%$ \\
\hline Environment & $3.2 \%$ & $1.0 \%$ & $1.0 \%$ & $8.7 \%$ \\
\hline $\begin{array}{l}\text { Development and hous- } \\
\text { ing }\end{array}$ & $3.8 \%$ & $4.4 \%$ & $5.5 \%$ & $4.0 \%$ \\
\hline $\begin{array}{l}\text { Civic and advocacy } \\
\text { associations }\end{array}$ & $6.1 \%$ & $2.6 \%$ & $1.9 \%$ & $1.8 \%$ \\
\hline $\begin{array}{l}\text { Philanthropic intermedi- } \\
\text { aries }\end{array}$ & $0.0 \%$ & $0.3 \%$ & $0.0 \%$ & $1.1 \%$ \\
\hline International activities & $0.4 \%$ & $1.3 \%$ & $1.8 \%$ & $3.0 \%$ \\
\hline $\begin{array}{l}\text { Professional associa- } \\
\text { tions, unions }\end{array}$ & $6.1 \%$ & $2.9 \%$ & $1.8 \%$ & $6.6 \%$ \\
\hline $\begin{array}{l}\text { Total } \\
\text { (the last } 6 \text { groups) }\end{array}$ & $19.6 \%$ & $12.4 \%$ & $12.0 \%$ & $25.3 \%$ \\
\hline TOTAL & $100 \%$ & $100 \%$ & $100 \%$ & $100 \%$ \\
\hline
\end{tabular}




\subsection{Revenue sources of the French third sector}

Table 2 and graph 3 show the overall importance of the three major sources of income of the French nonprofit sector: public funding, private earned income and private giving. With 58 per cent of the total, public resources have a large preponderance, coming primarily from social security, secondly from central government and, last but not least, from local governments. Private earned income covers slightly more than one third of the total resources: commercial resources - i.e. fees, charges and sales - are the main component, followed by membership dues and finally, at a very low level, by investment income. Private giving is low: it covers only 7.5 per cent of the total resources of the French nonprofit sector, one half coming from individual contributions, the other half coming from corporate giving or sponsorship.

Table 2 and Graph 3: Sources of revenue of the nonprofit sector in France, 1995

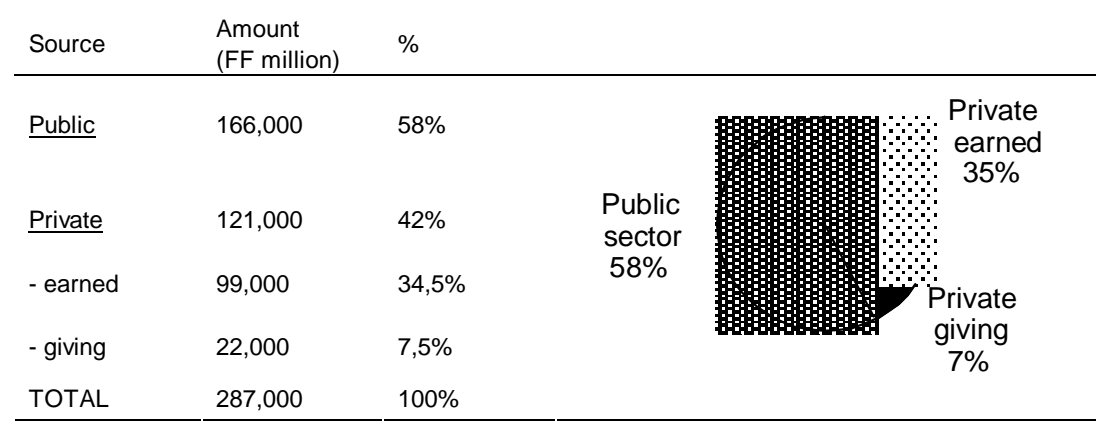

Source: Johns Hopkins Nonprofit Sector Comparative Project - Phase 2

This support structure is typical of Western European countries. Table 3 shows that the nonprofit sectors of all Western European countries included in the Johns Hopkins Comparative Nonprofit Sector Project - except for Spain - are government-dominant in their funding structure. France ranks at a low-average position among these countries: the relative share of public funding is smaller than it is in Ireland, Belgium, Germany or the Netherlands, but higher than it is in Austria and the UK. 
Table 3: Sources of nonprofit revenue by country 1995

\section{(19-country-average)}

\begin{tabular}{llll} 
& Private earned & Public sector & Private giving \\
\hline Fee-dominant & & & \\
Mexico & $85 \%$ & $9 \%$ & $6 \%$ \\
Peru & $68 \%$ & $19 \%$ & $13 \%$ \\
Australia & $62 \%$ & $31 \%$ & $6 \%$ \\
Japan & $62 \%$ & $34 \%$ & $3 \%$ \\
Finland & $58 \%$ & $36 \%$ & $6 \%$ \\
US & $57 \%$ & $31 \%$ & $13 \%$ \\
Slovakia & $56 \%$ & $21 \%$ & $23 \%$ \\
Hungary & $55 \%$ & $27 \%$ & $18 \%$ \\
Romania & $54 \%$ & $11 \%$ & $36 \%$ \\
Spain & $49 \%$ & $32 \%$ & $19 \%$ \\
Government-dominant & & & \\
Ireland & $15 \%$ & $78 \%$ & $7 \%$ \\
Belgium & $18 \%$ & $77 \%$ & $5 \%$ \\
Germany & $32 \%$ & $64 \%$ & $3 \%$ \\
Israel & $26 \%$ & $64 \%$ & $10 \%$ \\
Netherlands & $36 \%$ & $60 \%$ & $2 \%$ \\
France & $35 \%$ & $58 \%$ & $7 \%$ \\
Austria & $44 \%$ & $50 \%$ & $6 \%$ \\
UK & $45 \%$ & $47 \%$ & $9 \%$ \\
Czech Republic & $40 \%$ & $43 \%$ & $18 \%$ \\
TOTAL & $47 \%$ & $42 \%$ & $11 \%$ \\
\hline
\end{tabular}

Source: Salamon and al. Johns Hopkins Nonprofit Sector Comparative Project - 1998

The overall composition of the resources of the French third sector hides a wide range of funding patterns among the different activities, as graph 4 shows it. Health, education and social services are the only industries predominately funded by public money, they are also 'closer to the welfare state'. Other activities show a greater variety of sources of support: philanthropic intermediaries are mainly financed by giving while commercial resources provide for culture and recreation, development and housing, environment and professional associations. For civic associations public funding and commercial resources are balanced and the same is true for international activities where public funding - coming mainly from the European Union - and private giving are balanced. 
Graph 4: Revenue sources by subsector, 1995

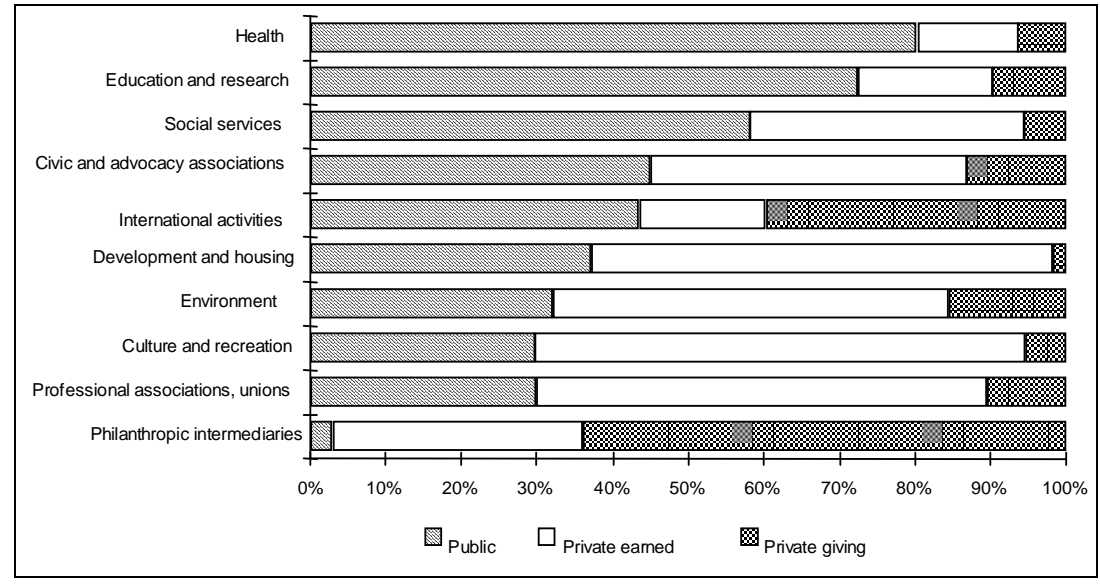

Source: Johns Hopkins Nonprofit Sector Comparative Project - Phase 2.

\subsection{The evolution of the French third sector (1990-1995)}

Between 1990 and 1995, nonprofit employment has shown a rapid growth of 20 per cent, from 803,000 to 960,000 FTE wage-earners. This result is noteworthy because during the same period total employment has declined by one per cent. The trend of nonprofit employment (1990-95) has several causes:

- During this period of time, male employment has declined while female employment has increased, this trend benefits nonprofit employment which is 70 per cent female.

- Moreover, employment has declined not only in agriculture and manufacturing but also in commercial and financial service activities. Only relational service activities, either market or non-market, have shown a growth in employment. Nonprofit organisations provide mainly relational services: out of 157,000 jobs created by the third sector from 1990 until 1995 one half has been created in the social services and one sixth in the culture and recreation subsector.

- Finally, the third sector has played a pioneering role in the labour market policies as we will see hereafter.

During the 1990-95 period, volunteer work has grown faster than paid employment, with a 10 per cent average annual growth. Its highest growth rate 
has occurred in the social services industry. Against the background of the deepening of depression, volunteer work appears as a way to obtain results rapidly at the local level, while public policies appear to be inefficient

There has been little change in the composition of the nonprofit sector within five years; as mentioned before, the preponderance of social services has even been increased. The structure of revenue sources shows a slight trend towards the privatisation of resources: a little less public funding, a little more earned income. Against the background of the results of the Johns Hopkins Comparative Nonprofit Sector Project, the following section will focus on how nonprofit organisations are actively forming a partnership with public entities, specifically in health or social services.

\section{New forms of partnership between the public and the nonprofit sector}

For the two last decades nonprofit organisations have been partners of a new welfare mix. Today they play also an increasing role in labour market policies. Of course, these two points are linked. France - just as Germany - is generally characterised as a corporatist welfare state (Esping Andersen, 1990): in order to acquire social rights, an individual has to have worked previously during a minimum duration. Therefore, in such a welfare system long-term unemployment means poverty - at the same token the access to the labour-market represents the key for social rights.

\subsection{The position of the nonprofit organisations in labour market policies}

During the last two decades, nonprofit organisations have secured their position -within or outside the framework of public labour market policies in order to help specific categories of unemployed people to enter or re-enter in the labour market.

One of the strategies of public labour market policy from 1991 onwards until today has been to offer part-time collective-utility jobs to young unemployed people or to the long-term unemployed. The wage bill is paid mainly by the government and symbolically by the recipient organisation - be it a public agency, a local community or a nonprofit organisation. The job must 
not compete with any regular paid job; training and supervision are to be ensured by the recipient organisation and half of the worker's time is to be devoted to job search and continuing education. Under these specific conditions nonprofit organisations have created many jobs, but evaluation studies show that, after the helped contracts, many of the participants of these programmes fall back into unemployment.

In 1997 these collective-utility jobs have become reserved for severe social cases and in 1998, more jobs - also paid mainly by the government were offered to qualified young people (emplois-jeunes). Once more, nonprofit organisations acted as employers for these emplois-jeunes, After three years of existence, nonprofit organisations are the main employers of these jobs, after public schools and gymnasiums and before the police force.

The nonprofit organisations have acquired a position as job providers also outside the framework of public labour market policies. From the early 1980s onwards some nonprofit organisations have specialised in "integration through an economic activity, called entreprises d'insertion (integration enterprises) or associations intermédiaires (intermediary associations). The entreprises d'insertion provide goods or services in activities either overlooked by standard businesses or in competition with them; the associations intermédiaires supply temporary manpower to non-market employers, households, nonprofit organisations or public agencies. However, for both organisations, the main objective is to help the most severely deprived people to join the mainstream and maybe to enter the standard labour market through training programs and on-the-job training. These direct agents of employment policies deal with very difficult economic and social situations: unskilled school drop-outs, potential or former delinquents, alcoholics and drug-addicts. The main resource of these nonprofit organisations is the product of their economic activity but the time spent to train or follow-up the apprentices is compensated by tax or social contribution cuts and by grants. Evaluation studies show that the "integration through an economic activity" organisations have been more efficient than any other training programme in the $1980 \mathrm{~s}$, but their scope was reduced by the deepening of the depression during the early 1990s (Gariazzo, 1998). In 1998, a Law to fight deep poverty, prepared by the government with 18 specialised nonprofits, decided that the number of integration enterprises has to be doubled and proposed increased incentives

Beyond this role in the professional and social integration of frail populations, nonprofit organisations are also creating new job opportunities through their standard activity - whatever its field.

For example, quite frequently nonprofit organisations are founded - by 
young people eager to be self-employed or by former executives who have some capital of their own - for the purpose of testing a business project. The very simple legal status of associations is used as an incubator for enterprises: if the project proves to be viable, the "business in disguise" achieves a standard business legal status, it becomes a corporation or limited liability enterprise. In the same direction some associative or cooperative incubators where created to employ unemployed youth.

But even more importantly, nonprofit organisations have been, are and will be pioneers in exploring new service activities. These activities may become either market or public services or stay in the nonprofit sector. In this context a prime example is the Club Méditerranée that was at first a nonprofit organisation of social tourism. Moreover, many professional football clubs were initially nonprofit organisations. New skills are also frequently tested by volunteer work turning into paid employment when the activity is growing, very often through public funding. This has been the case for social work during the interwar and postwar period and, more recently, for environmental jobs, sports, cultural management, training, or homework specialised in the aid of dependent people. The professionalisation-cycle is marked by the creation of professional associations, by new diplomas testifying the new skills, and sometimes by a specific collective bargaining. Let us note that two third of the 22 new jobs created by the emplois-jeunes have first been tested in nonprofit organisations. In that sense, volunteer work is a matrix or blue print of future labour, a testing area for flexible employment and an element of transitional labour markets (Schmid and Auer 1997; Gazier, 1998, Schmid and Gazier 2002).

\subsection{Nonprofit organisations are partners in a new welfare mix}

The development of a mixed provision system in the field of social services can be explained partly by a policy towards decentralisation which overcomes a thousand-year-old tradition of etatism, and partly by the initiatives of the nonprofit sector facing new social issues.

On the one hand, the Decentralisation Acts (1982-1983) have redistributed the responsibilities between the state and local governments. New activities and new resources were transferred to local governments ${ }^{1}$ who on their part contracted out the provision of many services. The nonprofit sector has been the main partner in the field of culture and arts, sports, education 
and training, and, above all, social welfare services outside the social security system. This has to be seen against the background of the welfare state being severely criticised - in France as elsewhere - for the inefficiency of public policies, the weight of bureaucracy, the tendency to create irresponsible beneficiaries and their inadequacy to cope with evolving needs.

According to Ullman (1993), the "delegation to nonprofit organisations has been the result of the deliberate effort on the part of political elites to improve the functioning and extend the scope of both social service provision and of French democracy (...) it was an effort to right the imbalance between an overly centralised and insular state and a weak and fragmented civil society". Also, public authorities have been overwhelmed by a growing demand for more diversified social services and again it has been the nonprofit organisations who were able provide specific types of services to more consumerist users. Moreover, the nonprofit sector has been very innovative in coping with new social issues. Since the social security scheme only deals with a limited number of social risks, it has been the third sector to first meet the needs of the handicapped, the rehabilitated alcoholics or drugaddicts, the pre-delinquent, the dependent elderly and so on.

More generally speaking, the third sector has coped with social prevention, social exclusion, and rural desertification at the local level because nonprofit organisations can mix social services delivery with advocacy far better than public agencies could do it. Nonprofits are also able to build new solidarity networks, for instance among the persons struck down by a rare disease or among the victims of the same natural or manmade disaster. Finally, they have access to specific resources, such as giving and volunteering $_{2}$ and to proximity saving networks or joint-ventures which again lowers their costs.

What kind of partnership results from this new welfare-mix? A labour division between the public and the nonprofit sector emerges according to which the state provides standard and basic services towards the whole population and also those services which are either highly health-related or linked to regalian functions - law and public order or justice, for example. The third sector provides personal and specialised services directed to minority groups and endangered populations or services involving moral support, the amelioration of family relations or a labour-using following-up. According to the subsidiary principle - a newcomer in France - the bulk of resources of the nonprofit organisations providing these social services is coming from government at its different levels, with variations according to the subfields: public funding is higher for facilities and services intended for the disabled, while users fees cover a lager part for day care, elderly homes, 
or home care services.

The large-scale public funding in the field of social services is balanced by various regulations related to the creation, costs and activities of nonprofit establishments. Habilitation, accreditation, agrément are different forms of contracts granted by the administration with a discretionary decision. They imply a control of the skills of the staff and of the quality of the delivered services. The reciprocal commitments are written down in those contracts. Nonprofit leaders regret that annual contracts can be revised by the administration unilaterally and ask for pluri-annual contracts which permit long-term planning. They also fear to become mere tools in the hands of public authorities. Conversely, central or local government ask for more accountability on the part of the nonprofit organisations.

While forprofit providers have firmly established the health field for several decades now, they still play only a small role in the provision of social services in France. The one exception are residential facilities for the elderly and home services where forprofits have been attracted by a more solvent population thanks to tax incentives. However, the competition between nonprofit and forprofit providers cannot be compared to the situation in UK or Italy, and tenders are not as common as in those countries. In France the trend towards "quasi-markets" was condemned by the left government (1997-2002) which criticised tax incentives for home services as favouring the wealthy strata of population only. Accordingly, the government reduced the tax incentives so that private companies are no longer as interested in "proximity services" as they were some years ago.

Certainly, the most interesting role of the nonprofit organisations in the welfare partnership is their recent involvement in the definition of public policies as it has been the case with the 1975 Law on Disabled People, the 1988 Act creating a Minimum Income, and the 1998 Law Against Social Exclusion. Nonprofit organisations are considered to be the representatives of the underprivileged stratum of the population. Besides the labour-unions which are the representatives of the workers - they are the advocates of the out-of-work just as they are the advocates of the "-less": the homeless, the identity-paper-less, the right-less, the stateless...

\section{Conclusion}

To conclude on the new welfare mix, nonprofit organisations are trying to meet some of the new challenges of the XXI century. Amongst those are: 
- First and foremost, the ageing of the population - by 2020 the number of dependent elderly is expected to be 1.2 million, nearly twice today's number. Community-care and continuing care will grow; they offer a trust-relationship and a co-ordination with the family that give a relative advantage to nonprofit organisations. Following the German position, the French social security has recently, in 2000 , decided to cover the dependency risk by a specific benefit according to the level of dependency and means-tested. However the funding of dependency expenditures is still a mix of various resources. Recently, some nonprofit organisations have also specialised in the tutelage of dependent people.

- The family policy is more and more oriented towards the conciliation of professional and family lives, and the nonprofit organisations have afforded many innovative responses to this problem. Their responses characteristically provide educational and recreational activities to the children and the youth during the out-of-school time. Nonprofit daycares are also more flexible than the public ones are and more fitted to the various time-schedule of working parents

- The social exclusion of unskilled young people and the urban deprived areas are also major social issues - we have seen above the role of nonprofit organisations in the social integration policy. Furthermore, the activities of immigrant nonprofit organisations aiming at equal opportunities for nationals and non-nationals in the fields of employment, housing, education and social life are crucial for the fight against racist or crypto-racist behaviours.

- The growth of solitude in our society can be seen when comparing the successive population censuses. It is partly a consequence of the ageing of the population, partly of the growth of divorce and partly of the growing mobility of the population. This rising degree of solitude goes with less family solidarity and also less social rights, therefore it predisposes to poverty. By providing other neighbourhood social ties, nonprofit organisations can play a part in solving this new social issue.

- Finally, the third sector can help to build a social and citizen Europe as it is a pioneer on the way towards citizenship and everyday-democracy. Many nonprofit organisations are already involved in European networks, such as the Red Cross, the Caritas, or youth organisations. A European association legal status is on the agenda and European umbrellas appear step by step. Without any doubt the third sector has an important role to play in promoting citizenship and responsibility among its members and is able to balance self-interest, the basis of a market-based economic union, by a sense of public interest, shared with 


\section{the future political institutions.}

\section{References}

Archambault, Édith. 1997a. The Nonprofit Sector in France. The Johns Hopkins Nonprofit Sector Series. Manchester: Manchester UP.

Archambault, Édith. 1997b. "Der Dritte Sektor in Frankreich: vom Jakobinischen Staat zur Dezentralisierung." In: Anheier, Helmut K., Eckhard Priller, Wolfgang Seibel und Annette Zimmer (eds.). Der Dritte Sektor in Deustchland. Berlin: Sigma: pp. 97-209.

Archambault Édith 1999 "Le secteur associatif en France et dans le monde" in Bloch-Lainé F. Faire Société. Les associations au cœur du social, Paris, Syros.

Archambault, Édith and Marie Gariazzo. 1998. Intermediaries Associations and Integration Enterprises. Report, Johns Hopkins Nonprofit Sector Comparative Project. Fondation de France.

Archambault E. and J. Boumendil, "Dilemmas of Public/Private Partnership in France", in U. Ascoli and C. Ranci, Edrs, Dilemmas of the Welfare Mix, New York, Kluwer and Plenum, 2002, p.109-134.

Bloch-Lainé, François. 1995. "Identifier les associations de service social." Revue internationale de l'économie sociale. $\mathrm{n}^{\circ} 251,49, \mathrm{p}$ 61-72.

Bloch-lainé, F. (1999) : Faire Société. Les associations au cœur du social, Syros

Boissonnat, Jean. 1995. Le travail dans vingt ans. Editions Odile Jacob. La Documentation Française, Paris.

Enjolras, Bernard. 1995. Le Marché Providence. Paris: Desclée de Brouwer.

Esping-Andersen, Gøsta. 1990. The Three Worlds of Welfare Capitalism. Princeton: Princeton UP.

Gazier, Bernard. 1998. "Ce que sont les marchés transitionnels." Cahiers du Centre d'Etudes de l'Emploi. 37. pp. 339-355.

Salamon, Lester M.. 1995. Partners in Public Service: Government - Nonprofit Relations in the Modern Welfare State. Baltimore: The Johns Hopkins University Press.

Salamon, Lester M. and Helmut K. Anheier. 1996. The Emerging Nonprofit Sector - A Comparative Analysis. Manchester: Manchester UP.

Salamon, Lester M. and Helmut K., Anheier (eds.). 1998. The emerging Sector Revisited. A summary. The Johns Hopkins University, Baltimore.

Salamon Lester. Anheier Helmut. and associates (1999). Global civil society: Dimensions of the Nonprofit Sector, Baltimore, The Johns Hopkins Center for Civil Society Studies.

Schmid, Günter and Peter. Auer. 1997. "Transitional Labour Markets. Concepts and Examples in Europe." Conference 'New Institutional Arrangements in the Labour Market'. European Academy of the Urban Environment. April 1997. Berlin.

Schmid, Gunter and Gazier Bernard, 2002 The Dynamics of Full Employment; Social Integration through Transitional Labour Markets, Cheltenham, Edward Elgar,

Ullman, Claire. 1993. "New Social Partners: Nonprofit Organisations and the Welfare State in France." Annual Meeting of the American Political Science Association. May 1993. Washington. 